\title{
The Influence of Voluntary Disclosure, Stock Beta, and Firms Size on Cost of Equity Capital
}

\section{Yati Mulyati}

Department of Accounting Faculty of Economics University of Widyatama Bandung

Jl. Cikutra No. 204A Bandung, 40125, Indonesia

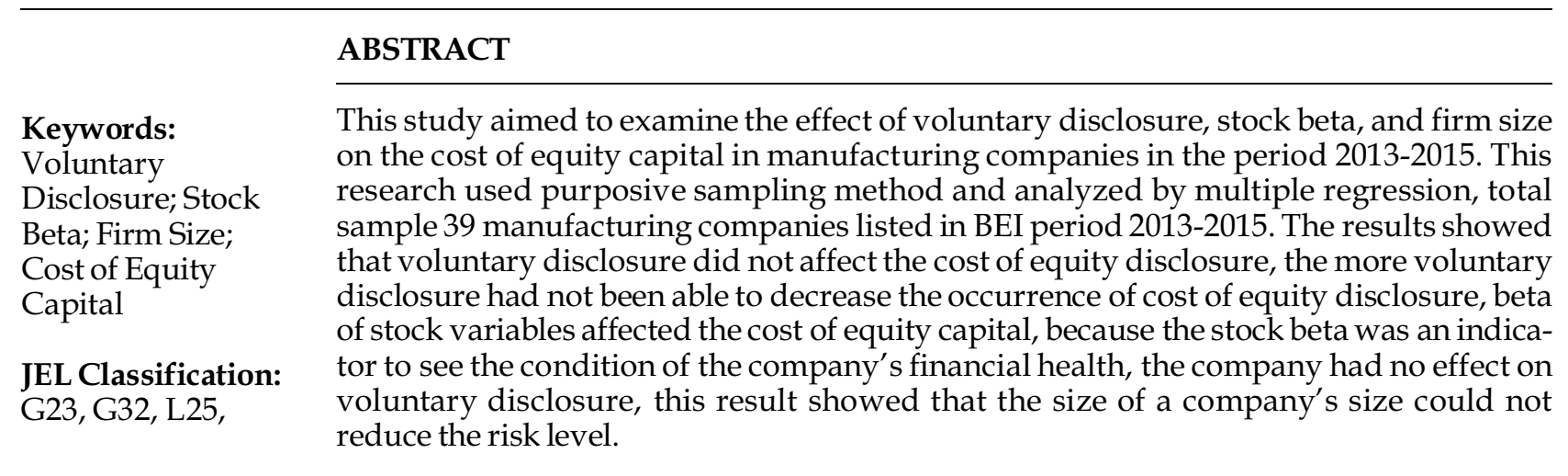

ABSTRAK

Penelitian ini bertujuan menguji pengaruh voluntary disclosure, beta saham, dan ukuran perusahaan terhadap cost of equity capital pada perusahaan manufaktur periode 2013-2015.

Kata Kunci:

Voluntary

Disclosure; Beta

Saham; Ukuran

Perusahaan; Cost of

Equity Capital
Penelitian ini menggunakan metode purposive sampling dan dianalisis dengan regresi berganda, total sampel 39 perusahaan manufaktur yang terdaftar di BEI periode 2013-2015. Hasil penelitian menunjukkan voluntary disclosure tidak berpengaruh terhadap cost of equity disclosure, semakin luas voluntary disclosure belum mampu menurunkan terjadinya cost of equity disclosure, variabel beta saham berpengaruh terhadap cost of equity capital, dikarenakan beta saham merupakan indikator untuk melihat kondisi kesehatan keuangan perusahaan, variabel ukuran perusahan tidak berpengaruh terhadap voluntary disclosure, hasil ini menunjukkan besar kecilnya suatu ukuran perusahaan tidak dapat mengurangi tingkat risiko. 
Cost of equity is a financial concept that can show the relationship between long-term investment decisions of the company with the rate of return that should be accepted. The cost of capital can be defined as the rate of return required by the user of the capital itself on an investment to keep the stock price unchanged. The cost of capital is recognized as the rate of return required to meet commitments made to shareholders while the cost of equity is related to the risk of investing in the company's shares. Management may not invest shareholder money if they cannot generate returns that are at least equal to what shareholders earn when investing in another place at the same risk (Djakman, 2001; Murni, 2004; Indayani \& Mutia, 2013).

Cost of equity capital (CEC) can be identified as the minimum rate of return required by the use of own capital on investment (Armadi \& Anggraeni, 2010). Botosan (1997) revealed that the more complete the level of accounting disclosures presented in the financial statements the lower the cost of equity capital. This suggests that information asymmetry between the investor (owner) and manager becomes lower and investor trusts the information presented by the company, so the expected minimum return will be lower.

Voluntary disclosure is more information disclosure than required, as it is deemed relevant to the needs of users of financial statements that management considers relevant in decision making (Meek, Roberts, \& Gray, 1995; Armadi \& Anggraeni, 2010). The research conducted (Fahdiansyah, 2016) showed that voluntary disclosure, stock beta, and firm size variables partially influenced the COC. Whereas the information asymmetry and institutional ownership variables partially showed no effect on COC while Gulo (2000), found that the variables of the voluntary disclosure index submitted by firms in the annual financial statements did not have a significant negative relationship with the estimated cost of equity capital of the firm in contrast to the research undertaken, Murni (2004) examined the relationship between the extent of voluntary expression, information asymmetry, and cost of equity capital. In calculating the cost of equity capital used an approach of CAPM (Capital Asset Pricing Market). The results show that the voluntary disclosures made by management in the company's annual report do not lower the company's cost of equity capital.

Beta is a measure of the volatility return of a securities or return portfolio on market returns. Beta shares are used as a basis of consideration before forming a portfolio (Yustiantomo, 2009). The size of the company's stock beta will cause the cost of equity capital of the company will be greater. This is due to an increase in systematic risk that occurs will be followed by an increase in the desired rate of return (cost of equity capital) by investors (Febrian, 2007).

Increased disclosure of information can have an impact on the decline in information asymmetry that may ultimately reduce the risk of a security. This decrease in risk will subsequently affect the decrease of the company's capital cost (Diamond \& Verrecchia, 1991; Murni, 2004). Issuance of shares or bonds resulted in the company must pay as a refund of the grant provided by investors and creditors, the cost is called the cost of capital (cost of equity capital). Capital cost is the minimum income level required by the owner of capital (Astria \& Khairani, 2012). Indonesia in general, the higher the cost of capital in a company then the impact is large enough for investment, where at least companies that do the public offering of shares, and the low activity of companies to seek funds (Indayani \& Mutia, 2013). Important capital costs are considered especially in long-term investment decision-making (Astria \& Khairani, 2012). Due to the overall cost of the company's capital will reflect the combined costs of all the financial resources used by the company. The cost 
reflects the financing which is the rate of return the company must earn, so it can compensate creditors and shareholders with the required returns (Putri, 2013).

The larger the size of the company, the greater the disclosure that needs to be disclosed (Jensen \& Meckling, 1976). The size of the company is also a consideration for investors in investing. Large companies tend to disclose more information for several reasons, ie, in an effort to reduce agency costs, can invest in various types of businesses, more easily enter the capital market and obtain bank loans (Murwaningsari, 2012). While Mardiyah (2002) tested firm size interaction with disclosure and test of disclosure interaction with information asymmetry. In this research company size proxy by using total assets of the company. The results show that firm size has a positive relationship with disclosure level and disclosure negatively related to information asymmetry.

The importance of understanding the cost of equity capital becomes the basis for the company in financing expenditure as well as making long-term investment decisions both and information relevant to voluntary disclosure, stock beta, and company size. Based on the description of the background that has been proposed, this study aims to examine the effect of voluntary disclosure, stock beta, and company size to cost of equity capital.

\section{HYPOTHESES DEVELOPMENT}

Theoretically, the wider voluntary disclosure that companies make indicates to investors will lower transaction costs and risks expected by investors over the performance of the company. The results of research conducted (Murni, 2004; Indayani \& Mutia, 2013) conducted research during 2007-2010 against 26 companies regarding the influence of information asymmetry and voluntary disclosure of the cost of equity capital. The results show that information asymmetry and voluntary disclosure have an influence on the cost of equity capital. While Putri (2013) and Dewi, Wahyuni, \& Sujana (2017) research, the results showed that disclosure likes negative effect on the cost of capital equity. While research by Astria \& Khairani (2012), the results showed that only beta market variables significantly influence the cost of equity capital while variable voluntary disclosure rate does not significantly influence the cost of equity capital and research results by Gulo (2000) positive but not significant between voluntary disclosure and cost of equity capital. This shows that the extent of voluntary expression is still inadequate so as not to have an impact or effect on the decrease of cost of equity capital. Then the research first hypotheses is:

$\mathrm{H}_{1}$ : voluntary disclosure affects the cost of equity capital

According to Jones (1991) and Murwaningsari (2012) states that beta is a relative measure of risk in its effect with the market as a whole money is measured from fluctuations in return. Increased disclosure of information can have an impact on the decline in information asymmetry that may ultimately reduce the risk of a security. This decrease in risk will subsequently affect the decrease of company's capital cost (Jones, 1991; Murwaningsari, 2012). A number of beta shares given to investors as return on investment gave the company will cause the cost of equity capital of the larger companies. This is consistent with the research conducted by Gulo (2000), Murni (2004), Astria \& Khairani (2012), and Dewi, Wahyuni, \& Sujana (2017), hence the research second hypotheses is:

$\mathrm{H}_{2}$ : beta stocks affect the cost of equity capital

Research by Mardiyah (2002) examines the firm size interaction by disclosure and testing of disclosure interactions with information asymmetry. The results showed that firm size was positively related to disclosure level and disclosure 


\section{Jurnal Keuangan dan Perbankan | KEUANGAN}

Vol. 21, No. 3, Juli 2017: 387- 396

was negatively related to information asymmetry and Embong, Mohd-Saleh, \& Hassan (2012) conducted a study of the firm size and voluntary disclosure of the cost of equity capital. The results show that voluntary disclosure has an influence on the cost of equity capital in large firms, whereas voluntary disclosure does not have an effect on the cost of equity capital in small firms. In contrast to research conducted by Komalasari \& Baridwan (2001), the results show that the greater decrease in information asymmetry experienced by large firms compared with small firms, resulting in a decrease in COC for large firms is higher when compared with small firms. These results indicate the influence of firm size on the cost of capital. The research conducted by Botosan (1997), Gulo (2000), and Mangena, Pike, \& Li (2010) suggests a significant negative relationship between firm size and cost of equity capital, as well as a significant positive relationship between beta and cost of equity capital. From the background that has been put forward the third hypotheses of this study:

$\mathrm{H}_{3}$ : firm size affects the cost of equity capital

\section{METHODS}

This research uses a quantitative approach with explanatory research type. Explanatory research is a research that explains the causal relationship between variables through testing other hypotheses. This study aims to measure the extent of cost of equity capital can be affected by voluntary disclosure, stock beta, and size company at manufacturing companies listed on the Indonesia Stock Exchange (BEI) in 2013-2015.

The population in this study is a manufacturing company listed on the Indonesia Stock Exchange. The sampling method in this research is using purposive sampling. Based on the criteria and selection conducted, obtained 39 companies that have met the criteria. The sample selection in this study, a manufacturing company listed on the Indonesia Stock Exchange which publishes an annual report for the period 2013-2015. The sampling criteria of companies that have never experienced delisting from the IDX period 2013-2015, a company that has never changed its business sector, companies that use the rupiah currency $(\mathrm{Rp})$, has a

Table 1. Operational Variables

\begin{tabular}{|c|c|c|c|}
\hline Variable & Concept Variable & Indicator & Scale \\
\hline $\begin{array}{l}\text { Voluntary } \\
\text { Disclosure }\left(\mathrm{X}_{1}\right)\end{array}$ & $\begin{array}{l}\text { The measurement of the area of voluntary disclosure } \\
\text { is done by a disclosure index that lists voluntary } \\
\text { disclosure items. The more voluntary disclosure } \\
\text { items contained in the annual report, the greater the } \\
\text { index of the company's voluntary disclosure. }\end{array}$ & $\begin{array}{l}\text { Index = number of total } \\
\text { score disclosure/ maximum } \\
\text { number of scores }\end{array}$ & Ratio \\
\hline Stock Beta $\left(\mathrm{X}_{2}\right)$ & $\begin{array}{l}\text { Beta is a systematic risk measurement of a securities } \\
\text { or portfolio relative to market risk }\end{array}$ & Rit $=a_{i}+R_{M t}+\epsilon_{i t}$ & Ratio \\
\hline Size Firm $\left(X_{3}\right)$ & $\begin{array}{l}\text { In determining the size of the company size is } \\
\text { expressed in total assets, total sales and market } \\
\text { capitalization. }\end{array}$ & Ln Total Aktiva & Ratio \\
\hline $\begin{array}{l}\text { Cost of Equity } \\
\text { Capital }(\mathrm{Y})\end{array}$ & $\begin{array}{l}\text { Cost of capital is a number of costs incurred by a } \\
\text { company to provide information to the public } \\
\text { (shareholders, investors, government, creditors, and } \\
\text { society in general) }\end{array}$ & $\mathrm{Ks}=\mathrm{R}_{\mathrm{f}}+\beta \mathrm{i}\left(\mathrm{R}_{\mathrm{mt}}-\mathrm{R} f\right)$ & Ratio \\
\hline
\end{tabular}


value beta (B) is not equal to 0 and does not exceed of 3 thus avoiding bias in testing the data.

This study uses 3 independent variables and 1 dependent variable. Independent variables in this study include voluntary disclosure, stock beta, and firm size while the dependent variable in this study includes the variable cost of equity capital. The operational explanation of variables in this study showed in Table 1.

\section{RESULTS}

The results of descriptive statistics can be seen in Table 2.

Descriptive analysis results revealed that the minimum value of voluntary disclosure of 39 companies during the period 2013-2015 with an aver- age value of 0.40 with a standard value of 0.10164 higher than the average during the study period is performed while the minimum value of 0.28 and the maximum value of 0.49 . The voluntary disclosure categories revealed by many of the companies sampled in this study are in the background information categories, projected information, explanations of discussion and analysis of management, and corporate governance.

Descriptive analysis results revealed that the minimum value of beta shares of 39 companies over the period 2013-2015 with a mean value of 1.4285 with a standard value of 0.95787 higher than the average during the study period while the minimum value of 0.03 and a maximum value of 2.78 . This shows the beta variable of stock to the cost of capital equity of excellent data distribution.

Table 2. Descriptive Analysis Results

\begin{tabular}{llrrrr}
\hline & N & \multicolumn{1}{c}{ Min } & \multicolumn{1}{c}{ Max } & Mean & Std. Deviation \\
\hline Voluntary Disclosure & 39 & .28 & .49 & .4054 & .10164 \\
Beta Saham & 39 & .03 & 2.78 & 1.4285 & .95787 \\
Size Perusahaan & 39 & 25.24 & 28.89 & 27.3721 & .98330 \\
Cost of Equity Capital & 39 & .84 & 1.26 & 1.0451 & .10731 \\
Valid N (listwise) & 39 & & & & \\
\hline
\end{tabular}

Table 3. Results of Partial Correlation Coefficient

\begin{tabular}{|c|c|c|c|c|c|}
\hline & & $\begin{array}{l}\text { Cost Of } \\
\text { Equity } \\
\text { Capital }\end{array}$ & $\begin{array}{l}\text { Voluntary } \\
\text { Disclosure }\end{array}$ & $\begin{array}{c}\text { Beta } \\
\text { Saham }\end{array}$ & Size \\
\hline \multirow{4}{*}{$\begin{array}{l}\text { Pearson } \\
\text { Correlation }\end{array}$} & Cost of Equity Capital & 1.000 & .161 & .442 & .112 \\
\hline & Voluntary Disclosure & .161 & 1.000 & .293 & -.039 \\
\hline & Stock Beta & .442 & .293 & 1.000 & .459 \\
\hline & Firm Size & .112 & -.039 & .459 & 1.000 \\
\hline \multirow{4}{*}{$\begin{array}{l}\text { Sig. } \\
\text { (1-tailed) }\end{array}$} & Cost of Equity Capital & . & .164 & .002 & .249 \\
\hline & Voluntary Disclosure & .164 & . & .035 & .407 \\
\hline & Stock Beta & .002 & .035 & . & .002 \\
\hline & Firm Size & .249 & .407 & .002 & . \\
\hline \multirow[t]{4}{*}{$\mathrm{N}$} & Cost of Equity Capital & 39 & 39 & 39 & 39 \\
\hline & Voluntary Disclosure & 39 & 39 & 39 & 39 \\
\hline & Stock Beta & 39 & 39 & 39 & 39 \\
\hline & Firm Size & 39 & 39 & 39 & 39 \\
\hline
\end{tabular}




\section{Jurnal Keuangan dan Perbankan | KEUANGAN}

Vol. 21, No. 3, Juli 2017: 387- 396

Descriptive analysis results show that the minimum value of firm (size) of 39 companies during the period 2013-2015 with a mean value of 27.3721 with a standard value of 0.958330 higher than the average during the study period while the minimum value of 25.24 and a maximum value of 28.89. This shows the size of the firm (size) to the cost of capital equity data distribution is very good and the average size of the company is high.

\section{Classic Assumption Test}

The results of normality test data by using Kolmogrof-Smirnov (K-S) test resulted in a significance of 0.800 , which showed greater than 0.05 then the data is normally distributed. Subsequent normality test data using histogram graphs gives normal distributed data results, this is indicated by a histogram graph that does not lean to the left or right. Data distribution around the diagonal line and following the diagonal line direction is the result shown on the data normality test using the P-Plot Graph.

The result of multicollinearity test result using VIF (Variance Inflation Factors) and tolerance value, voluntary disclosure has VIF 1.142 and tolerance value 0.876 . Beta stock obtained VIF 1444 and calculation of tolerance value 0.693 , while size of the company produces VIF 1.321 and tolerance value 0.757 . It was concluded that there was no multicollinearity among independent variables in the regression model used.

The result of heteroscedasticity test by using scatterplots chart shows spreading point randomly and well spread, thus indicating no heteroscedasticity in the regression model used. The results of the autocorrelation test using the Durbin-Watson statistic test resulted in a value of 1.951, located in the range 1.55-2.46. It shows no autocorrelation.

\section{Analysis Correlation Coefficient between Variables}

The analysis of the relationship between voluntary disclosure, stock beta, firm size to the cost of equity capital, is presented in Table 3.

The result of correlation analysis test can be seen that the correlation coefficient between the voluntary disclosure $\left(X_{1}\right)$ is 0.161 , beta shares $\left(X_{2}\right)$ of 0.442 , and size of company $\left(\mathrm{X}_{3}\right)$ of 0.112 to variable cost of equity capital (Y).

The test result of the partial correlation coefficient of voluntary disclosure with the cost of equity capital is 0.161 . Giving an interpretation of the correlation coefficient of $r$ value, the closeness of the category is very low, positive, and unidirectional, which gives the higher the level of voluntary disclosure, the greater the value of the cost of equity capital.

Value of correlation coefficient beta share with the cost of equity capital equal to 0.442 . This is included in the category of being, is positive and shows a unidirectional relationship, which gives a greater meaning of the value of the beta stock than the greater the value of the cost of equity capital.

The correlation coefficient of 0.112 for the correlation of firm size with the cost of equity capital, indicating closeness included into the very low category, positive value, and unidirectional relationship means the bigger the size of the company the greater the value of the cost of equity capital.

\section{Multiple Regression Analysis}

This test is intended to decide whether to accept or reject testing of variables based on the data obtained from the research sample. The results of multiple regression analysis can be known after performing statistical tests to determine the 
magnitude of the relationship between variables studied. The statistical test consists of determination coefficient test $\left(\mathrm{R}^{2}\right)$, Simultaneous Test $(\mathrm{F}-$ Test), and Partial Test (T-Test).

The coefficient of determination determines the contribution of Voluntary disclosure affecting the cost of equity capital is 2.59 percent, the contribution of the beta share influences cost of equity capital is 19.53 percent, and contribution of firm size influences cost of equity capital is only equal to 1.25 percent. While the value of the coefficient of determination (Adjusted R-Square) is 0.138 , gives the meaning that the ability of the explanatory variable is the dependent variable capable of affecting the independent variable of 13.8 percent, while the rest is explained by other variables outside the regression model. The regression equation is depicted by the following regression equation:

$Y=1,293+0,023 X 1+0,055$ X2 - 0,012X3, can be seen in Table 4.

From the above equation, it can be concluded that: (1) the value of interception coefficient of 1.293 is positive which indicates when voluntary disclosure, stock beta and firm size is zero, then the cost of equity capital is worth 1.293 ; (2) the value of the voluntary disclosure regression coefficient of 0.023 is positive, indicating that if each voluntary disclosure increases by 1 unit, then the cost of equity capital of 0.023 units with the condition of other variables is considered constant; (3) the value of the beta stock regression coefficient of 0.055 is positive, indicating that if the stock beta increases 1 unit, then the cost of equity capital of 0.055 units with the condition of other variables is considered constant; and (4) the coefficient of firm size regression value is -0.012 indicates that if inflation rises by 1 unit, it will decrease the cost of equity capital equal to 0,012 unit with a condition of other variable is considered constant.

\section{DISCUSSION}

\section{Partial Testing (T-Test)}

Based on Table 4, partial test results (t-test) show the effect of voluntary disclosure, stock beta," and firm size to cost of equity capital. This test is done using significance level 0.05 ( $\alpha=5$ percent). Acceptance or rejection of the partial test is done

Table 4. Multiple Regression Analysis Results

\begin{tabular}{|c|c|c|c|c|c|c|}
\hline \multirow{2}{*}{\multicolumn{2}{|c|}{ Model }} & \multicolumn{2}{|c|}{$\begin{array}{l}\text { Unstandardized } \\
\text { Coefficients }\end{array}$} & \multirow{2}{*}{$\begin{array}{c}\text { Standardized } \\
\text { Coefficients } \\
\text { Beta }\end{array}$} & \multirow[t]{2}{*}{$\mathbf{t}$} & \multirow[t]{2}{*}{ Sig. } \\
\hline & & B & Std. Error & & & \\
\hline \multirow[t]{4}{*}{1} & (Constant) & 1.293 & .536 & & 2.411 & .021 \\
\hline & Voluntary Disclosure & .023 & .283 & .013 & .080 & .937 \\
\hline & Stock Beta & .055 & .020 & .490 & 2.705 & .010 \\
\hline & Firm Size & -.012 & .019 & -.112 & -.647 & .522 \\
\hline
\end{tabular}

Table 4. Partial Test Results (T-Test)

\begin{tabular}{lccc}
\hline \multicolumn{1}{c}{ Variabel Independen } & T Arithmetic & T Table & Significance \\
\hline Voluntary Disclosure & 0.080 & 2.0280 & 0.937 \\
Stock Beta & 2.705 & 2.0280 & 0.010 \\
Firm Size & -0.647 & 2.0280 & 0.552 \\
\hline
\end{tabular}


when $\mathrm{t}$ arithmetic $>\mathrm{t}$ table or probability $<$ level of significance ( $\mathrm{Sig}<0.05$ ), then $\mathrm{H}_{0}$ is rejected and $\mathrm{H}_{\mathrm{a}}$ accepted means independent variables affect the dependent variable. If $\mathrm{t}$ arithmetic $<\mathrm{t}$ table or probability $>$ level of significance (Sig $>0.05$ ), then $\mathrm{H}_{0}$ accepted and $\mathrm{H}_{\mathrm{a}}$ rejected means the independent variable has no effect on the dependent variable. Table 4 partially tested the relationship between voluntary disclosure, stock beta, and firm size variables on the cost of equity capital.

\section{The Effect of Voluntary Disclosure Against Cost of Equity Capital}

Variable voluntary disclosure, significance value of $0.937>0.05$, meaning $\mathrm{H}_{0}$ accepted and $\mathrm{H}_{\mathrm{a}}$ rejected. The decision result of voluntary disclosure variable has no significant effect on the cost of equity capital.

The results of this study are in accordance with the research by Gulo (2000), Astria \& Khairani (2012), and Dewi \& Chandra (2016) stating that voluntary disclosure has a positive relationship and has no significant effect on the cost of equity capital. This is because the information submitted by management in the company's annual report is still not in accordance with the needs of investors in understanding the risks of future investment as well as the Indonesian capital market belonging to the efficient capital market in the form of weak so that the information disclosed by the company in the annual report does not affect the cost of equity capital because the disclosure of the company is still voluntary rather than mandatory disclosure.

\section{The Effect of Stock Beta on Cost of Equity Capital}

Variable stock beta, significance value of $0.010<0.05$, means that $\mathrm{H}_{0}$ is rejected and $\mathrm{H}_{\mathrm{a}}$ accepted. The result of a decision of beta variable of stock there is a significant influence to cost of equity capital and beta share have the direct relationship with the cost of equity capital.

The results of this study are consistent with the research by Gulo (2000), Murni (2004), Fahdiansyah (2016) and Dewi, Wahyuni, \& Sujana (2017), stating that the larger the company's beta stock, the cost of equity capital of the company will also be greater. The results of this study are in line with the theory that risk estimation is directly proportional to the expected rate of return. This means that the increased systematic risk that occurs in a company is followed by an increase in the desired rate of return (cost of equity capital).

The results show that implicitly beta stock is a parameter of a company's financial condition, whether the company is healthy or the company is approaching the failure of the market (delisting). Because if the issuer is delisted from the stock then the investor is the most disadvantaged party. Investors will bear the risk if their investment portfolio involves potentially failed stocks, as investors can no longer trade their shares. Beta is believed as a factor affecting the cost of equity capital of a company, where the level of risk estimation of a company decreases, then the rate of return will also decrease so that cost of equity capital will eventually be lower.

\section{Influence Size Company Against Cost of Equity Capital}

Variable company size, significance value of $0.552>0.05$, it can be concluded $\mathrm{H}_{0}$ accepted and $\mathrm{H}_{\mathrm{a}}$ rejected. The result of firm size decision is not significant influence to cost of equity capital. The results of this study also show that the voluntary disclosure, stock beta, and firm size variables partially influence $\mathrm{COC}$, while the information asymmetry and institutional ownership variable partially show no effect on COC. 
The size of the company does not significantly affect the cost of equity capital because the size of the company has not automatically provided assurance to investors in determining stock returns. The amount of cost of equity capital is determined by the level of risk in investing. Investors tend to assume that large companies have a lower risk level than small firms. In reality, however, large companies will not escape the political pressure of pressure to carry out external responsibilities and social responsibility. As a result, large companies reduce their financial statements in order to maintain their good name so that financial statements are not reported in real circumstances and will increase the level of risk. Level of risk cannot be seen only from the size of a company so that cost of equity capital cannot be determined just by looking at the size of a company.

\section{CONCLUSION AND SUGGESTIONS}

\section{Conclusion}

Based on the results of research and analysis that have been done related to the purpose of research to determine the effect of voluntary disclosure, stock beta, and firm size to cost of equity capital. It can be made conclusion, voluntary disclosure variable test results to cost of equity capital that the more voluntary disclosure has not been able to reduce the transaction costs along with risks analyzed by investors on the company's performance.

The result of testing beta variable stock to cost of equity capital, that the bigger beta level of stock at the company will reduce the level of emitter risk. This indicates the stock beta is a parameter to the company's financial condition to determine the level of health and corporate failure so that investors know more about the impact of potential risks to the company in the sale of shares.

The result of the testing variable of firm size to the cost of equity capital shows the size of a company's measure impact on risk and responsibility in conveying company's financial information. The size of the company cannot be an information on risk management.

\section{Suggestions}

This research still has limitations, therefore there are several suggestions as follows: (1) for the company, to pay more attention to the considerations of the occurrence of cost of equity capital so that will not cause the cost of capital; (2) further research, this research uses only company delisting at BEI, expected to use other company as sample of research and add variable asymmetry of information, earnings management and institutional ownership as well as grouping size of company big and small in order to know direct influence to cost of equity capital; and (3) due to the influence of the independent variable is still small to the dependent variable, it is advisable to add another independent variable that will affect the cost of equity capital.

\section{REFERENCES}

Armadi, H. \& Anggraeni, M.D. 2010. Pengaruh Pengungkapan Sukarela pada Cost of Equity Capital dengan Asimetri Informasi sebagai Intervening Variabel. Trikonomika, 9(1): 62-71.

Astria, T. \& Khairani, S. 2012. Pengaruh Tingkat Pengungkapan Sukarela dan Beta Pasar terhadap Cost of Equity Capital (Studi Kasus Perusahaan Industri Barang). Jurnal Akuntansi S1 STIE MDP, 1-8.

Febrian, B. 2007. Pengaruh Pengungkapan Sukarela, Beta saham, dan Ukuran Perusahaan terhadap Cost of Equity Capital Pada Perusahaan Manufaktur yang Go Public di Indonesia. Skripsi. Universitas Brawijaya Malang.

Botosan, C.A. 1997. Disclosure Level and the Cost of Equity Capital. The Accounting Review, 72(3), 323-349.

Dewi, L.P.K.S., Wahyuni, M.A., \& Sujana, E. 2017. Pengaruh Asimetri Informasi, Pengungkapan 


\section{Jurnal Keuangan dan Perbankan | KEUANGAN}

Vol. 21, No. 3, Juli 2017: 387- 396

Sukarela, Manajemen Laba, dan Beta Saham terhadap Cost of Equity Capital. E-Journal S1 Ak Universitas Pendidikan Ganesha Jurusan Akuntansi Program S1, 7(1): 1-12.

Dewi, S.P. \& Chandra, J.S. 2016. Pengaruh Pengungkapan Sukarela, Asimetri Informasi, dan Manajemen Laba terhadap Cost of Equity Capital pada Perusahaan Manufaktur. Jurnal Bisnis dan Akuntansi, 18(1): 25-32.

Diamond, D.W. \& Verrecchia, R.E. 1991. Disclosure, Liquidity, and the Cost of Capital. The Journal of Finance, 46(4): 1325-1359.

Djakman, C. 2001. Dasar-Dasar Manajemen Keuangan. Edisi Ketujuh. Jakarta: Salemba Empat.

Embong, Z., Mohd-Saleh, N., \& Hassan, M.S. 2012. Firm Size, Disclosure, and Cost of Equity Capital. Asian Review of Accounting, 20(2): 119-139.

Fahdiansyah, R. 2016. The Influence of Voluntary Disclosure, Asymmetri Information, Stock Risk, Firm Size and Institutional Ownership Towards Cost of Capital (COC). Jurnal Aplikasi Manajemen, 14(2): 387-397.

Gulo, Y. 2000. Analisis Efek Luas Pengungkapan Sukarela dalam Laporan Tahunan terhadap Cost of Equity Capital Perusahaan. Jurnal Bisnis dan Akuntansi, 2(1): 45-62.

Indayani \& Mutia, D. 2013. Pengaruh Informasi Asimetri dan Voluntary Disclosure terhadap Cost of Capital pada Perusahaan Manufaktur yang Terdaftar di Bursa Efek Indonesia. Jurnal Reviu Akuntansi dan Keuangan, 3(1): 373-382.

Jensen, M. \& Meckling, W. 1976. The Theory of Firm: Managerial Behavior, Agency Costs, and Ownership Structure. Journal of Financial Economics, 3(4): 305-360.
Jones, J.J. 1991. Earnings Management during Import Relief Investigations. Journal of Accounting Research, 29(2): 193-228.

Komalasari, P. \& Baridwan, Z. 2001. Asimetri Informasi dan Cost of Equity Capital. The Indonesian Journal of Accounting Research, 4(1).

Mangena, M., Pike, R., \& Li, J. 2010. Intellectual Capital Disclosure Practices and Effects on the Cost of Equity Capital: UK Evidence. Dissertation. The Institute of Chartered Accountants of Scotland.

Mardiyah, A.A. 2002. Pengaruh Informasi Asimetri dan Disclosure terhadap Cost of Capital. Jurnal Riset Akuntansi Indonesia, 5(2).

Meek, G.K., Roberts, C.B., \& Gray, S.J. 1995. Factors Influencing Voluntary Annual Report Disclosures By U.S., U.K., and Continental European Multinational Corporations. Journal of International Business Studies, 26(3): 555-572.

Murni, S.A. 2004. Pengaruh Luas Ungkapan Sukarela dan Asimetri Informasi terhadap Cost of Equity Capital pada Perusahaan Publik di Indonesia. Jurnal Riset Akuntansi Indonesia, 7(2): 192-206.

Murwaningsari, E. 2012. Faktor-faktor yang Mempengaruhi Cost of Capital (Pendekatan: Structural Equation Model). Jurnal Ekonomi dan Bisnis Airlangga, 22(2): 157-172.

Putri, E. 2013. Pengaruh Luas Pengungkapan Sukarela terhadap Biaya Modal dengan Asimetri Informasi Sebagai Variabel Intervening (Studi Empiris pada Perusahaan Manufaktur yang Terdaftar di BEI). Jurnal Akuntansi, 1(1): 1-27.

Yustiantomo, S.B. 2009. Analisis Faktor-faktor yang Mempengaruhi Beta Saham. Disertasi. Universitas Diponegoro. 